\title{
Filipeni, 3, 8 în limba română: un caz de primat al normei
}

\author{
Adina Chirilă ${ }^{A\left[\mathbb{R}^{0}\right.} 8$ * \\ Facultatea de Litere, Istorie și Teologie, Universitatea de Vest, Bd. Vasile Pârvan 4, 300223 Timişoara, România
}

\begin{abstract}
Despre articol
Istoric:

Primit 4 aprilie 2020

Acceptat 7 aprilie 2020

Publicat 10 iunie 2020

Cuvinte-cheie:

semantică istorică

limbă literară

filologie

traducere

Rezumat

În lucrarea de faţă, studiul variantelor pe care traducătorii textului biblic în limba română le-au dat în epoca veche și contemporană fragmentului de sub Filipeni,

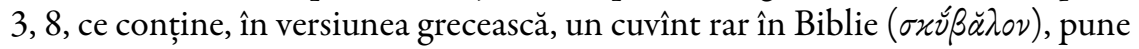
în evidență faptul că actul traducerii așază textul pe făgașul unei limbi, supunîndu-1 stării limbii de la un moment dat și evoluției acesteia. În orice moment, se manifestă o ajustare formală, ce urmează la ceea ce se consideră a fi corect ori cel puțin posibil din punct de vedere lingvistic: mai întîi, este cea a textului străin la limba nouă, româna; apoi, este cea a textului românesc la înnoirile limbii române-ajustare care poate să ignore, de la un moment dat în istoria producerii și receptării textului respectiv în limba și cultura română, solicitările originare; astfel, corectitudinea textului e controlată de norma limbii și de aparența de acuratețe semantică a lui.

În ultima secvență din $F i l, 3,8$, istoria redării elementului comparației în limba română constituie un caz foarte bun de primat al normei limbii asupra conținutului originar (în raport cu textul-sursă direct) - recuperabil, dar exclusiv pe cale metalingvistică.
\end{abstract}

\section{Introducere}

\subsection{Un cuvînt rar în Biblie}

Lucrarea de față este un studiu al variantelor pe care traducătorii textului biblic în limba română le-au dat în epoca veche și contemporană unui verset din Noul Testament, ce conţine, în versiunea grecească,

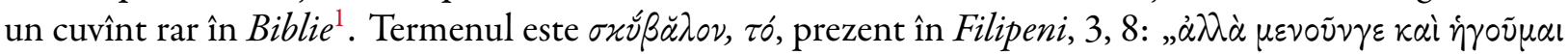

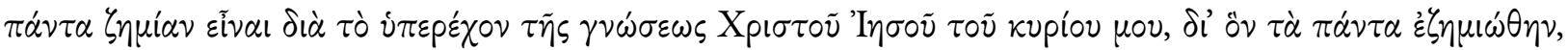

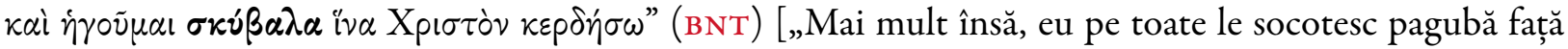
de neprețuitul preț al cunoașterii lui Hristos Iisus, Domnul meu, de dragul Căruia m’am lăsat păgubit de toate și le socotesc drept gunoaie pentru ca să-L cîștig pe Hristos”, Anania 2001].

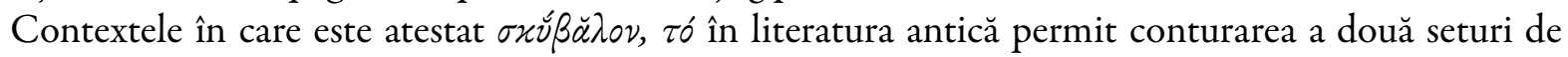
definiții pentru acesta:

a) 'ceea ce se aruncă, gunoaie, resturi' [engl. refuse, offal, LIDDELL-SCOTT s.v.; fr. débris jeté de côté, restes d'un repas, débris rejetés par la mer, BAILLY s.v.],

b) 'excremente' [engl. (human) excrement, dung, manure, LIDDELL-SCOTT s.v.; fr. excrément, BAILLY s.v.].

În ansamblul literaturii elene, termenul este mai degrabă rar, prezent ceva mai frecvent în documentele

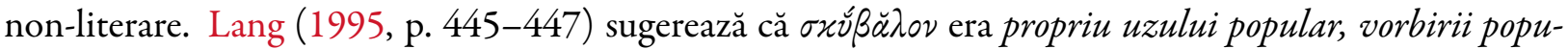
$\operatorname{lare}^{2}$; autorii eleni „au ezitat” să-l folosească (după cum rezultă și la o căutare a cuvîntului în baza de date

*Adresă de corespondență: chiriladina@yahoo.com.

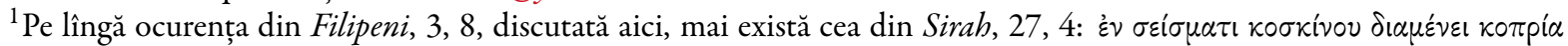

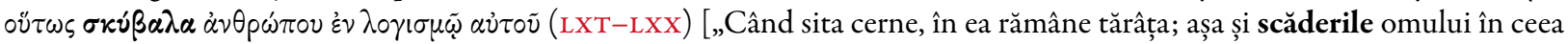
ce vorbește", Anania 2001].

${ }^{2}$ Cf. BAIlly, s.v., „familier”. 
$\mathrm{TLG}^{3}$-numai 178 de ocurențe din 65 de milioane de cuvinte, la 3165 de autori, aproape absent la autorii din generațiile postpatristice!), utilizînd, în schimb, în contexte specifice, sinonime: xó $\pi \rho \circ \zeta, \dot{\eta}$ (cu 1736 de

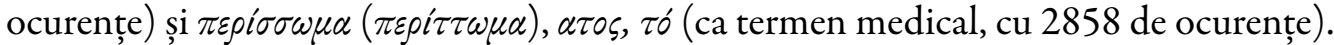

Ca termen-tabu în seria lui sinonimică, dintr-un registru inferior, cuvîntul $\sigma x \tilde{\beta} \beta a ̆ \lambda o v$ pare că este perceput ca inadecvat uzului cult și, prin urmare, puternic conotat atunci cînd se apelează la el (v. Trudgill, 1981). Totuşi, observația are caracter general, iar întrebarea: In ce măsură este indreptățită această viziune asupra termenului în sine intr-un text dat, precum cel paulinic, ținînd cont de contextul istoric, temporal al utilizării sale? este cu totul pertinentă.

\subsection{Motivare pragmatică}

Indubitabil, în unele texte antice din preajma momentului în care se consemnează activitatea apostolică,

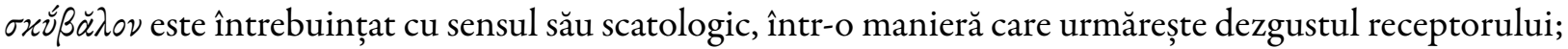
în aceeași perioadă însă, este înregistrată și utilizarea cu sensul mai puțin agresiv ${ }^{4}$; astfel încît, pe baze lexicologice și lexicografice, este neclar care dintre grupele de sensuri atribuite termenului ar trebui activată în momentul citirii unui text oarecare, fie și într-o recreare a realităților sociale, comportamentale și de comportament lingvistic ale sec. I.

În acest caz, atribuirea lecțiunii acurate a unui cuvînt este nevoie să se întemeieze pe lecțiunea atribuită textului care cuprinde cuvîntul respectiv, hermeneutica trebuind să apeleze la argumente retorice și doctrinare.

Versetul la care ne referim este parte a unei polemici susținute de mai multe ori de către Pavel $^{5}$. În Romani (2, 25-29), de pildă, ca și în Filipeni (3, 1-9), se argumentează superioritatea noului legămînt (prin credința în Isus Hristos), față de vechiul legămînt (prin respectarea tuturor regulilor), pentru a dobîndi „pace cu Dumnezeu” (Rom, 5, 1). Dar în timp ce persuasiunea din Romani se bazează pe logos (recursul la argumente raționale), în Filipeni dominante sînt persuasiunea prin ethos (Pavel—evreu cu totul îndreptățit prin lege—invocă experiența personală ca mărturie) și persuasiunea prin pathos (prin apeluri emotionale).

Între mijloacele lingvistice utilizate în construcția discursivă a emoțiilor, Plantin (2004) menţionează şi „enunțuri emoţionale” sau, mai corect, după cum rezultă din explicaţiile autorului, „enunțuri cu valoare emoțională” (emotional sentences, p. 268) - care țin locul, în discurs, lexicului emoțional propriu-zis și care, din punct de vedere lingvistic, fac legătura între un individ și un termen emoțional. Cu alte cuvinte, există situații în care discursul emoțional este definit de un material lingvistic a cărui componentă emoțională este declanşată de analogie (Plantin, 2004, p. 269). În pasajul din Fil, 3, 1-9, acest aspect din demersul

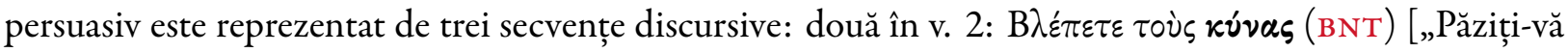

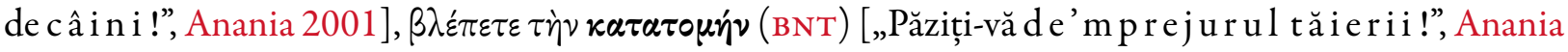

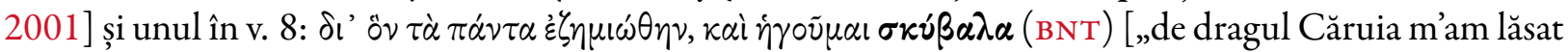
păgubit de toate și le socotesc drept g u n o a i e”, Anania 2001].

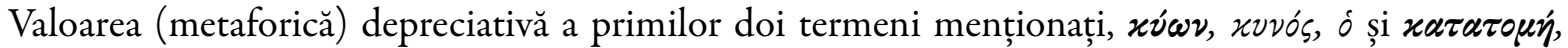
$\tilde{\eta} \varsigma, \dot{\eta}$, în contextul din Fil, 3, 2, este, de obicei, evidențiată (în dicționarele de limbă greacă, în lucrările lexicografice dedicate limbii Noului Testament, în comentariile care însoțesc traducerile moderne-de pildă, în ceea ce ne privește, în notele versiunii Anania 2001 a Bibliei):

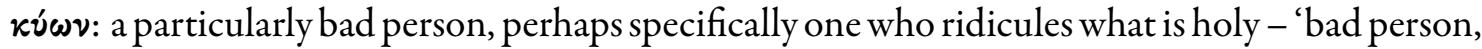
dog' (...) 'pervert' [rom. persoană rea, care ia în rîs ceea ce este sfînt - 'persoană rea, cîine' (...) perversă, în sens sexual] (LOUW-NIDA s.v.); a term of reproach for persons regarded as unholy and impure [rom. ...persoană lipsită de sfințenie, impură] (FRIBERG s.v.); of male sacred

\footnotetext{
${ }^{3}$ Cf. statisticile oferite de PDL pentru un corpus mai redus [online].

${ }^{4}$ Uzul, în ambele feluri, este documentat în amănunțime de către lexicologi și lexicografi; v. dicționarele citate mai sus, s.v.

${ }^{5}$ V. trimiterea din Fil, 3, 1: ,...Ca să vă scriu aceleaşi lucruri (s.n.), mie nu-mi este greu, iar vouă vă este întărire” (Anania 2001), „posibilă aluzie la o epistolă care nu s’a păstrat” (idem, nota $a$ ).
} 
prostitutes [rom. despre prostituații bărbați din practicile religioase idolatre] (LIDDELL-SCOTT s.v.) etc.;

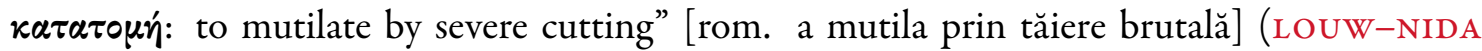
s.v.); strictly cutting into, as hacking or chopping up (sacrificial) meat [rom. a tăia, a măcelări carne destinată ritualului de sacrificare] (FRIBERG s.v.); „Între acest termen (katatomé) și cel din versetul următor (peritomé) e un sarcastic joc de cuvinte prin care Pavel asociază circumcizia iudaică (mai precis, pe cea a iudaizanților) cu automutilările corporale din ritualurile orgiastice păgîne" (Anania 2001, Fil, 3, 2, nota $b$ ) etc.

Alăturarea celor doi termeni și alegerea lor pentru desemnarea unor persoane care, practicînd circumcizia ca parte a unui ritual milenar de sfințire, se aflaseră, pînă nu demult, în canonul absolut corect și în regulă, trebuia să șocheze, să trezească o definitivă reacție de respingere. După crucificarea și învierea lui Hristos, practica circumciziei devenise nu numai superfluă, ci și ofensatoare, dovedind incapacitatea ,iudaizatorilor" de a înțelege absolutul jertfei lui Hristos pentru mîntuirea sufletului.

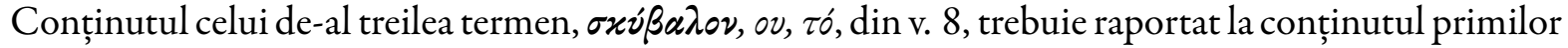
doi discutați. Imaginea de la sfîrșitul v. 8 reprezintă punctul culminant al diatribei lui Pavel împotriva pretenției îndreptățirii prin fapte (îndeplinirea ritualurilor, respectarea complexei legi veterotestamentare etc.), în opoziție cu îndreptățirea prin credință 6 . In contextul polemicii cu adversarii iudaizatori, discursul persuasiv adresat instabilei biserici din Filipi își asigură eficiențta prin utilizarea unui termen șocant, cu atît mai expresiv cu cît este preluat din vorbirea populară, dur, repulsiv, care redă nu doar ideea de lipsă de valoare, ci mai ales pe aceea a dezgustului. În contextul din Fil, 3, 8, cuvîntul discutat acceptă deci sensul scatologic și nuanța vulgară. Ideea se susţine inclusiv prin prisma a ceea ce nu este încă textul care îl conține: anume, scriere sacră, cu un atribuit caracter sobru, formal—care nu sînt altceva decît grevări culturale, eminamente posterioare producerii textului.

\section{Filipeni, 3, 8, versiuni românești}

\subsection{De la sl. orмМеты la rom. gunoi}

În faţa acestei realități textuale, traducerea pornește și se dezvoltă pe felurite căi, în funcție de ponderea unor factori care țin a) de capacitățile de înțelegere ale traducătorului și deci de nevoia sa de a exprima conținutul înțeles, b) de posibilitățile limbii în care se face traducerea, c) de acumulările culturale (cu tot cu prejudecăţile firești!) vizavi de receptarea și transmiterea textului și, nu în ultimul rînd, d) de distanța—în privința înlănțuirii interlingvistice—dintre sursa primordială și, în fapt, textul-sursă direct al unei traduceri (traduceri succesive produc modificări semantice, iar calitatea unei traduceri se judecă prin raportare la sursa ei directă).

La începutul sec. XVI, traducătorul textului ce ajunge să fie tipărit de Coresi la Braşov, în 1567, ca Lucrul apostolesc nu este pus în situația, nici măcar teoretică, de a se raporta la o tradiție formal-textuală românească, reflexul său de onorare a sacralității textului prin prezervarea formei nefiind în acest punct al traducerii altul decît cel care impune în mod obişnuit în această epocă traducerea „în literă”. Astfel, el se întemeiază pe ce înțelege și pe libertatea de a opera cu elementele limbii române în măsura pe care i-o îngăduie îndatorarea resimțită față de textul-sursă al său. În locul vizat (Fil, 3, 8), produsul este acesta: „Că aceaea toată o țin pagubă cătră pre cinstita cunoscuta lu Hristos Isus Domnului mieu. Derept aceaea acealea toate le-am socotit pagubă și mie o țin ca $\mathbf{u}<\mathbf{n}>$ gunoi să fie" (CA, s.n., A.C.), în raport cu un original a cărui identitate—slavonă sau germană—nu (mai) este sigură.

\footnotetext{
${ }^{6}$ De aici, caracterul pragmatic al epistolei: „Paul's intention was obviously to imbue his letters with power (s.n., A.C.) to convince and to persuade through the use of rhetorical rules, but without taking on the role of a sophist or a philosopher" (Dormeyer, 2004, p. 70).
} 
Problema modelelor Apostolului coresian a fost redeschisă de Costinescu (1980), după o perioadă de consens ce admitea exclusiv existența unor versiuni slavone la baza izvoarelor românești ale tipăriturii. Cercetătoarea introducea în discuție un text-sursă german (i.e. Biblia lui LutherL45), care ar justifica opțiuni lingvistice ale traducătorului și numeroase pasaje, „inexplicabile prin versiunile slavone reflectate de restul textului (ms. sl. BARSR 21 și 435)” (Costinescu, 1980, p. 129). Fragmentul de care ne ocupăm în cercetarea de față (i.e. Fil, 3, 8) nu apare între cele care sînt discutate de Mariana Costinescu și care, supuse fiind analizei lingvistice comparative, evidențiază o apropiere mai mare a textului tipărit coresian de versiunea germană mai ales în porțiunea ce corespunde epistolelor (idem, p. [135] şi [136]); este posibil ca cercetătoarea să-l fi omis întîmplător (nu și-a propus, de altfel, un demers exhaustiv, iar „,[e]xemplele [...] care să ilustreze dependența versiunii coresiene a Apostolului de textul german al lui Luther se pot înmulți”, idem, p. [134]), cum este posibil și să fi considerat că particularităţile lingvistice ce ar putea funcționa ca dovezi ale „abaterii” de la arhetipul slavon, respectiv ale „apropierii” de cel german nu sînt atît de grăitoare ca în alte cazuri (v. p. 129-[135]). Aplicînd modelul analitic al cercetătoarei bucureștene, observînd în paralel cele trei variante,

Că aceaea toată o țin pagubă cătră pre cinstita cunoscuta lu Hristos Isus Domnului mieu. Derept aceaea acealea toate le-am socotit pagubă și mie o țin ca $\mathbf{u}<\mathbf{n}>$ gunoi să fie $(\mathrm{CA})$,

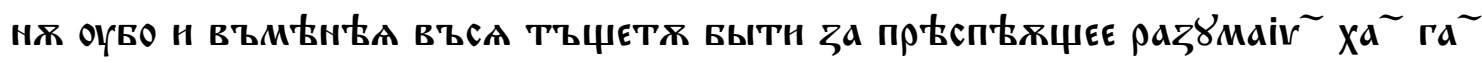

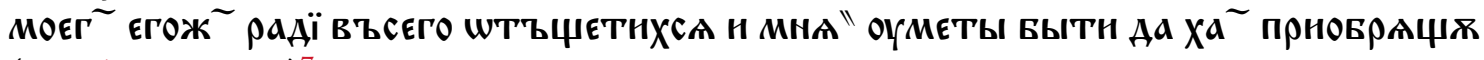
(ms. sl. BARSR 21$)^{7}$,

Denn ich achte es alles für Schaden gegen die überschwengliche Erkenntnis Christi Jesu, meines Herrn, um welches willen ich alles habe für Schaden gerechnet und achte es für Dreck, auf daß ich Christum gewinne (L45),

se constată că, strict la nivel lexical-semantic, opțiunile lingvistice ale traducătorului (ori ale diortositorului textului, înainte de tipărire) se află la egală distanţă faţă de ambele arhetipuri posibile, textul nesolicitînd alt material decît cel ce putea fi uzual românesc la mijlocul sec. XVI. Un element pare totuşi a avea o oarecare greutate în sprijinul ideii Marianei Costinescu, cel puțin în sensul colaționării versiunii românești pe baza și a unei versiuni germane. Este vorba despre o chestiune de compoziție a textului românesc, care face uz de echivalentul a ține, pentru sl. въмҺнитн (въмьнгатн), lat. 'putare' (MIKLOSICH s.v.) sau/și germ. achten, conform structurii explicite a versiunii luterane: astfel, repetarea verbului a ține în ,...toată o țin pagubă [...] și o țin ca $\mathrm{u}<\mathrm{n}>$ gunoi să fie...” corespunde repetiției prezente în germ. ,...ich achte es alles für Schaden [...] und achte es für Dreck..., față de situația din textul slavon ${ }^{8}$, unde verbul 'cunoașterii

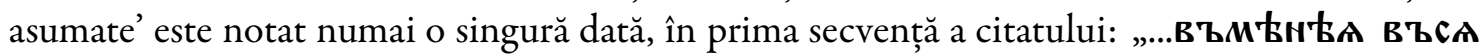

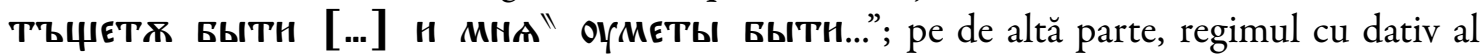
acestui verb ,adăugat” în textul românesc_,,...mie (o țin) ca $\mathrm{u}<\mathrm{n}>$ gunoi...”-indică în mod clar influența construcției slavone: „Мна " оцМеты”.

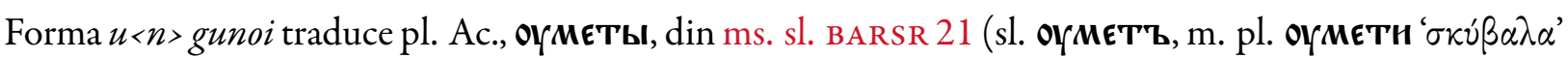

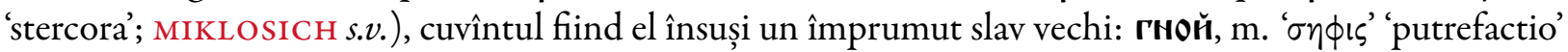

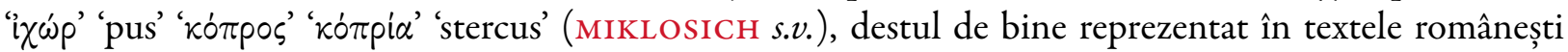

\footnotetext{
${ }^{7} \mathrm{Ne}$ exprimăm aici gratitudinea față de dl prof. univ. Gh. Chivu, care ne-a facilitat accesul la text; și față de dl. prof. univ. Richard Sârbu, care ne-a sprijinit în analiza gramaticală a fragmentului.

${ }^{8}$ Precizăm că nu ne-a fost accesibil textul ms. BARSR 435; cf. textul corespunzător din Biblia „Crkvenoslavenski” [online].

${ }^{9}$ Admitem însă că dacă cineva are a raporta textul românesc la mai mult de o limbă-sursă, i.e. la germană pe lîngă slavonă, se va baza pe observațiile Marianei Costinescu (v. Moldovanu, 2009, p. 106, care consideră că cercetătoarea bucureșteană ,a demonstrat în manieră categorică—s.n., A.C.—dependența unei părți a Apostolului coresian de Biblia lui Luther”), iar nu pe cele prezentate de noi.
} 
din secolul XVI. Contextele în care este întrebuințat—în afara celui din Lucrul apostolesc al lui Coresiîl indică incontestabil ca sinonim al lui or/METTh, cu un sens clar (sau, în unele cazuri, cel puțin foarte probabil) scatologic și scabros, ce ar corespunde setului al doilea de definiții (v. supra) al gr. $\sigma x \check{\beta} \beta a ̆ \lambda o v, \tau o ́:$

Zise cătră viiariul: „Iată, trei ani de cînd vii, caut rod la smochinul acesta și nu aflu. Taie-l, amu; derep ce și pămîntul deșartă?” El răspunse, zise lui: „Doamne, lasă-1 și în cest an, pînă o voi săpa împrejur și-i voi băga gunoi; și de, amu, va face rod, iară de nu, întru venire tăia-veri ia” (Ст),

Așa, amu, toți den voi şi de nu se va lepăda de toată avuțiia lui, nu poate fi mie ucenic. Bună sare; de se va sarea împuți, cu ce o veri săra? Nece în pămînt, nece în gunoi treabnică iaste, afară să o vărși. Cine are urechi de ascultare să auză! (Ст);

Unora le va fi fața ca țărâna pământului, alții ca tina spurcată din uliță, alții ca gunoiul (cTod; v. şi CST),

Și potrebiră-se în Indor și fură ca gunoiul pământului. (CPS-R; v. și PH, PS, PV),

$\mathrm{Nu}$ osîndireți să nu osîndiți fiți; cu ce judecată judeca-vreți, judeca-să-va voao, și cu ce măsură măsura-vreți, măsura-se-va voao. Ce vezi gunoiul în ochiul fratelui tău, vîrghiia în ochiul tău nu simți, sau cum grăești fratelui tău „Lasă-mă să iau gonoiul den ochiul tău și ia tu vîrghie din ochiul tău”. Fațarnice, <i>è mainte vîrghie den ochiul tău și atunce veri vedea a lua gunoiul din ochiul fratelui tău. ( $\mathrm{CB}$ ),

Domnul mesereaște și bogățeaște, și smereaște și rădică. Înalță de pământ measerul, și den gunoi rădică mişelul, să puie el cu tarii oamenilor și scaun slăvit să dea lui (CPS-R; v. și PS, PV, EP);

cf. gunoişte (sl. гнонште 'fimetum', MIKLOSICH 2 s.v.), gunosi (sl. гноуснттн са 'abominari', MIKLOSICH ${ }_{2}$; 'a se scîrbi', Rosetti, 1978, p. 594):

ce rrădică despre pămîntu mișelul și din gunoişte înrălță measerul (PV),

De toată mîncarea gunosi-se sufletul lor și apropiară-se pînă la ușa morției (PS).

Cuvîntul românesc nu cunoaște în sec. XVI forma de plural; așadar, utilizarea în Fil, 3, 8 a unui singular acolo unde textul-sursă slavon prezintă un plural nu ține de opțiunea traducătorului (care să fie, eventualîn cazul particular al CA-, orientată de existența unui singulare tantum în modelul german L45, i.e. Dreck), cîtă vreme limba română singură nu-și exersează o formă de plural care să scoată substantivul din categoria numelor de materie singularia tantum. Cînd apare însă, ea stimulează nuanțarea semantică a cuvîntului, ajungîndu-se (în plus față de ceea ce permitea sg. gunoi) la un rezultat care coincide cu

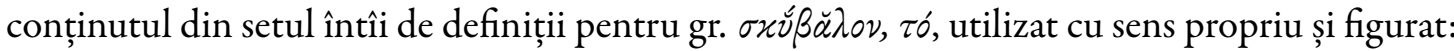

canoanele $85[\ldots]$ poruncim și noi să să ție întărite și adevărate, însă fără de poslaniile și răspunsurile lui Climent, că într-acelea multe taini, zizanii și gunoae de sminteală au băgat zlocestivii (р 1652);

Pre unii omora la casa lui și le ascundea trupurile în gunoaie (CM);

Iar dorobanții să bucura, și-i călca cu picioarele și-și bătea joc de trupurile lor. Și nici la bisérică nu-i lăsa să-i îngroape, ci afară prin gunoaie (IȚR);

într-acest chip sînt porțile Ierusalimului, care le-au zidit Noemiia, în urma mutării de la Vavilon: poarta împăraților, a preoților, a boiarilor celor de cinste, a norodului, a prorocilor și poarta pre care scotea din cetate gunoaele, precum să vede într-acest rotocol (AI/O);

sau, din secolul următor,

Încă și din afară pricini se întâmplă din lovitură, din răceală, sa $u$ di $n$ arsura capulu $i$ sa $u$ din nisca $i$ praf $u$, sa $u$ spurcăciune, sau gunoiu ${ }^{10}$ care întră în urechi. Dar uneori și fă $r$ ă > nicio îngrădire sau mișcare, singure urlă și țiuescu urechile (MD, I).

\footnotetext{
${ }^{10} \mathrm{Cf}$. „trupul să încălzeaște și să aprinde, gâdilire sau mușcare nu sâmte la pântece, nu iaste atâta lipsitu de pohta mâncării bolnavul. Gunoiul lui iaste albu, mai vârtos, turburatu” (MD, II; s.n., A.C.), unde aceeași formă prezintă, contextual, un conținut scatologic mult mai evident.
} 


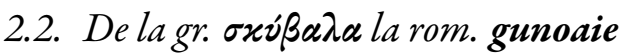

Din momentul în care limba îi oferă o paradigmă completă, traducătorul poate „emenda” formal versiunile românești din epoca precedentă, cu atît mai mult și mai îndreptățit din punct de vedere morfologic atunci cînd textul-sursă asupra căreia lucrează este grecesc ${ }^{11}$, iar acesta face uz în locul cu pricina de un plural:

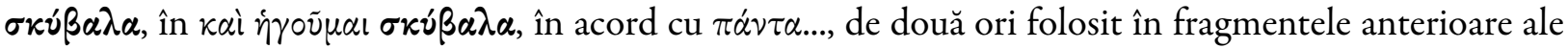
versetului: $v$.

B 1688: Ce pentru aceaea și gîndesc toate pagubă a fi, pentru cea ce covîrșaște a științii lui Hristos Isus, Domnului mieu, pentru care de toate $\mathrm{m}$-am păgubit și le gîndesc gunoaie a fi, ca pre Hristos să dobîndesc

в 1795: Iară mai vîrtos le socotesc să-și fie toate pagubă, pentru înălțimea cunoștinții lui Hristos Iisus, Domnului mieu, pentru Carele de toate m-am păgubit și le socotesc gunoaie, ca să dobîndesc pre Hristos

Indiferent de înțelegerea pe care traducătorul, judecînd contextul din Fil, 3, o are faţă de cuvîntul respectiv, redarea în limba română este mai înclinată să ia forma de pl. gunoaie în locul vizat ${ }^{12}$, instituindu-se în felul acesta o tradiție discursiv-formală a cărei forță hermeneutică rămîne să depindă de viața limbii (v. Darmesteter, 2015), i.e. de modulările semantice ale cuvîntului.

\subsection{Imposibila emendare}

În uzul comun, evoluția denotativă a subst. gunoi, pl. gunoaie este suficient de reținută încît să nu impună cu necesitate o revizuire a textului biblic în privința formei: mesajul general este prezervat, receptorul este satisfăcut. Totuși, traducătorul ori revizorul modern al scrierii poate resimți o pierdere în privința forței de simbolizare, pe care să vrea să o minimizeze printr-un demers oarecare. Diversitatea și eficiența acestuia se dovedesc însă a fi riguros controlate din mai multe direcții, care se ranforsează reciproc și care țin, esențialmente, de limbă. Prin calitatea dobîndită pe cale culturală, textul sacralizat respinge inovații lingvistice venite dinspre registrul puternic vulgarizant, ceea ce înseamnă că, în ciuda faptului că limba însăși ar putea oferi soluții multiple pentru redarea noțiunii vizate $a b$ initio ${ }^{13}$, traducătorul—țintind la realizarea unui text canonic—nu are acces la ele. Pe de altă parte, implicarea formei de singular, cum se procedează, de exemplu, în

Cornilescu 1921: Ba încă, și acum privesc toate aceste lucruri ca o pierdere, față de prețul nespus de mare al cunoașterii lui Hristos Isus, Domnul meu. Pentru el am perdut toate și le socotesc ca un gunoi, ca să cîștig pe Hristos,

\footnotetext{
${ }^{11}$ Cf. situația ce privește NT 1648, care orientează traducătorul spre selectarea unui termen de origine latină în Fil, 3, 8: „Ce iată le socotiiu a fi pagubă. Pentru înălțimea cunoștinției a lui Hristos Iisus Domnului mieu, pentru carele de toate mă păgubiiu și le socotiiu toate a fi ștercure, ca să dobîndescu pre Hristos”, după vUL: ,verumtamen existimo omnia detrimentum esse propter eminentem scientiam Iesu Christi Domini mei propter quem omnia detrimentum feci et arbitror ut stercora ut Christum lucri faciam" (s.n., A.C.).

${ }^{12}$ V. loc. cit. în, e.g., B 1914: „Iar mai vîrtos le și socotesc toate pagubă a fi pentru covîrșirea cunoștinței lui Hristos Iisus Domnul meu, pentru carele de toate m’am păgubit și le socotesc gunoaie a fi, ca pre Hristos să dobîndesc”; Cornilescu 1931: „Ci într'adevăr și socotesc că toate sînt pagubă pentru înălțimea cunoștinței lui Hristos Isus, Domnul meu, pentru care m’am păgubit de toate și le socotesc ca gunoaie ca să cîștig pe Hristos”; Anania 2001: „Mai mult însă, eu pe toate le socotesc pagubă față de neprețuitul preț al cunoașterii lui Hristos Iisus, Domnul meu, de dragul Căruia m’am lăsat păgubit de toate și le socotesc drept gunoaie pentru ca să-L cîștig pe Hristos”; B 2008: „Ba mai mult: eu pe toate le socotesc că sunt pagubă față de înălțimea cunoașterii lui Hristos Iisus, Domnul meu, pentru Care m-am lipsit de toate, și le privesc drept gunoaie, ca pe Hristos să dobândesc"; peste tot, s.n., A.C.

${ }^{13}$ Stimulate poate de exemplul unor versiuni care acceptă un termen/o construcție cu o conotație mai puternică: engl. dongue, dung (GNV, ETH, KJV, NET, KJ21, DRA etc.), dog dung (MSG), crap (AYB); germ. Kot (LUO). Cf. fr. boue (LSG, NEG), ordure (ТОВ), bon à être mis au rebut (BDS); engl. rubbish (NKJV, NIV etc.), useless rubbish (PILLIPS), garbage (TEV, NJB etc.), $\operatorname{dirt}(\mathrm{WE})$, worthless trash ( $\mathrm{NCV})$, refuse (YLT, ASV); toate, consultate prin bibleworks.com.
} 
NT Cat: ba, mai mult, de acum consider că toate sunt o pierdere în comparație cu superioritatea cunoașterii lui Cristos Isus Domnul meu. De dragul lui am pierdut toate și le consider gunoi ca să-l câștig pe Cristos

şi

FIDELA: Da, în adevăr, și socotesc toate lucrurile pierdere, din cauza măreției cunoașterii lui Cristos Isus, Domnul meu, pentru care am suferit pierderea a toate și le socotesc a fi gunoi, ca să câștig pe Cristos

pare să fi fost considerată o soluție alternativă de emendare textuală (probabil chiar într-o măsură mai mare în cazul celei catolice și al celei de-a doua versiuni protestante menționate ${ }^{14}$ ), însă efortul apare ca fiind gratuit: în cazul lui gunoi, niciuna dintre formele numerice ale substantivului nu a dezvoltat în timp un semantism aparte faţă de cealaltă ${ }^{15}$, deci singularul nu se sustrage semantismului dobîndit de cuvînt prin uzul comun și devenit prototipic; iar eventuala deschidere ${ }^{16}$ spre semantismul vechi, ce și-a păstrat caracterul prototipic în plan regional ${ }^{17}$, 'bălegar', nu se produce automat, în lipsa altor elemente de aceeaşi factură (i.e. regională) sau a unora co-textuale orientatoare. Iar mizarea, eventual, pe citirea eufemistică a lui gunoi-de data aceasta, din perspectiva unei percepţii contemporane urbanizate-ar întoarce lucrurile în punctul care s-ar fi dorit a fi depăşit, căci un atare demers lingvistic atenuează efectul.

Complinirea pragmaticii textului-dacă aceasta este văzută ca o necesitate—rămîne să fie realizată la nivel metalingvistic, în cadrul unui tip oarecare de paratext ${ }^{18}$.

\section{Concluzii}

Actul traducerii (înțelegînd prin aceasta inclusiv simpla intenție a traducerii lui) așază textul pe făgaşul unei limbi, supunîndu-l stării limbii de la un moment dat și evoluției acesteia (obținută pe diverse căi, grație plasticității naturale a sa ca instrument de comunicare a niște indivizi mînați de felurite nevoi). În orice moment, se manifestă o ajustare formală, ce urmează la ceea ce se consideră a fi corect ori cel puțin posibil din punct de vedere lingvistic: mai întîi, este cea a textului străin la limba nouă—româna (deschisă, eventual, ea însăși ajustării, prin împrumut, la cerințele venite dinspre conținutul textului); apoi, este cea a textului românesc la înnoirile limbii române-ajustare care poate să ignore, de la un moment dat în istoria producerii și receptării textului respectiv în limba și cultura română, solicitările originare; astfel, corectitudinea textului e controlată de norma limbii și de aparența de acuratețe semantică a lui.

În ultima secvență din $F i l, 3,8$, istoria redării elementului comparației în limba română constituie un caz foarte bun de primat al normei limbii asupra conținutului originar (în raport cu textul-sursă direct) recuperabil, dar exclusiv pe cale metalingvistică.

\footnotetext{
${ }^{14}$ Traducere care declară că urmează principiul echivalenței formale și că are ca surse Textul Masoretic si „familia grecească a Textului Receptus pentru NT" (v. Prefața la FIDELA), dar care este destul de puternic influențată de tradiții vernaculare occidentale.

${ }^{15}$ Cum se întîmplă în situația substantivelor singularia tantum nume de materie, din limba contemporană, la care forma de plural implică o modificare de sens: făină vs. făinuri 'sorturi de făină', carne vs. cărnuri 'sorturi de carne'; cf. situația din epoca veche, unde plurale precum foameți (v. Frâncu, 2009, p. 29), sîngiuri sau cărni, cărnuri (v. Chirilă, 2013, p. 158-161) puteau desemna tocmai 'mai multe exemplare de același fel', 'multitudinea de obiecte de același fel'.

${ }^{16}$ Vizată probabil prin utilizarea nearticulată a substantivului, în „le socotesc a fi gunoi”, FIDELA, și „le consider gunoi”, NT Cat; s.n., A.C.

${ }^{17}$ V. observația din Frățilă (2005), p. 172 și 176: „în graiul de pe valea inferioară a Târnavelor există o serie de termeni care formează arii lexicale în sudul și centrul Transilvaniei, deosebind graiul de aici de cel muntean, dar și de alte graiuri din Transilvania”, printre care „Gunoi 'bălegar' cuprinde Transilvania de centru și sud, sud-vestul Crișanei”.

${ }^{18}$ De pildă, în Indicele la MLD, XXIV, p. 860, se menționează în privința sensului, s.v. gunoi: „[...] 'Mist': 'fumier, fumure’”. De asemenea, indirect: între notele traducătorului-editor (Fecioru, 2016, p. 179) la traducerea sa din Clement Alexandrinul, Pedagogul. Cartea a II-a, apare una ce indică, de fapt, spre citirea „optimă” a pasajului de sub Fil, 3, 8; astfel, la „Aș vrea ca bogații să socotească toată viața aurul ca demn numai pentru excremente”, Fecioru creează nota 178: „Cf. Filipeni 3, 8”. Etc.
} 


\section{Bibliografie}

\section{A. Surse}

AI/O = Antim Ivireanul, Opere. Ediție de Gabriel Ștrempel, Editura Academiei, București, 1972.

Anania 2001 = Biblia sau Sfânta Scriptură. Ediție jubiliară a Sfântului Sinod, (...) redactată şi adnotată de Bartolomeu Valeriu

Anania, Editura Institutului Biblic și de Misiune al Bisericii Ortodoxe Române, București, 2001.

в 1688 = Biblia 1688, I-II. Text stabilit și îngrijire editorială de Vasile Arvinte și Ioan Caproșu, Editura Universității „Alexandru Ioan Cuza", Iași, 2001, 2002.

в 1760 = Biblia Vulgata, Blaj, 1760-1761. Cuvânt înainte de Eugen Simion, Editura Academiei Române, București, 2005.

в 1795 = Biblia de la Blaj, 1795. Ediție jubiliară, cu binecuvîntarea Î.P.S. Lucian Mureșan, Mitropolitul Bisericii Române Unite, Roma, 2000.

в 1914 = Biblia, adică Dumnezeeasca Scriptură a legii vechi și a celei nouă, Ediția Sfântului Sinod, Tipografia Cărților Bisericești,

București.

в 2008 = Biblia sau Sfânta Scriptură, Editura Institutului Biblic și de Misiune Ortodoxă, București.

Biblija „Crkvenoslavenski” [online].

BNT $=$ Novum Testamentul Grece. Nestle - Alland 27 ${ }^{\text {th }}$ Edition, Deutsch Bibelgesellschaft, Stuttgardt, 1993.

$\mathrm{CA}=$ Ioan Bianu (ed.), Texte de limbă din secolul al XVI-lea. IV. Lucrul apostolesc. Apostolul tipărit de diaconul Coresi in Braşov

la anul 1563, București, 1930.

св = Codicele Bratul. Ediție de text de Alexandru Gafton, Editura Universității „Alexandru Ioan Cuza”, Iași, 2003.

CM = Dan Horia Mazilu (ed.), Cronicari munteni, Minerva, București, 1978.

Cornilescu 1921 = Biblia sau Sfinta Scriptură a Vechiului și Noului Testament. Cu trimiteri. [Traducerea, D. Cornilescu], București.

Cornilescu 1931 = Biblia sau Sfinta Scriptură a Vechiului și Noului Testament. [Traducerea, D. Cornilescu], București.

$\mathrm{CPS}-\mathrm{R}=$ Coresi, Psaltirea slavo-română (1577), in comparație cu psaltirile coresiene din 1570 și din 1589, Text stabilit, introducere și indice de Stela Toma, Editura Academiei, [București].

CST = Codex Sturdzanus. Studiu filologic, studiu lingvistic, ediție de text și indice de cuvinte de Gh. Chivu, Editura Academiei,

București, 1993.

CT = Tetraevanghelul tipărit de Coresi, Braşov 1560-1561, comparat cu Evangheliarul lui Radu de la Mănicești, 1574. Ediție

alcătuită de Florica Dimitrescu, Editura Academiei, București, 1963.

CTod = Codicele Todorescu, BAR, ms. rom. 5484; colaționare, Gh. Chivu [online].

EP = Eustratie Logofătul, Pravila aleasă. Ediție, studiu introductiv, note și glosar de Alin-Mihai Gherman, Editura Academiei

Române, București, 2018.

FIDELA = Biblia, Editura Fidela, Cluj-Napoca, 2011.

$\mathrm{ITTR}=$ Stolnicul Constantin Cantacuzino, Istoriia Țărîi Rumânești. Cronicari munteni, vol. I, Minerva, București, 1984.

$\mathrm{L} 45=$ Luther (1545). Bible [online].

LXT-LXX = Septuaginta . Edited by Alfred Rahlfs, Württembergische Bibelanstalt / Deutsche Bibelgesellschaft, Stuttgardt, 1935.

MD = Meșteşugul doftoriei. Primul tratat românesc de medicină. Ediția manuscriselor românești BAR nr. 933 și 4841. Studiu

filologic, studiu lingvistic, ediție, glosar și indice de Lia Brad Chisacof, Editura Academiei, București, 2017.

ms. sl. BARSR $21=$ Apostol slavon, manuscris.

NT 1648 = Noul Testament. Tipărit pentru prima dată în limba română la 1648 de către Simion Ștefan, mitropolitul Transil-

vaniei, reeditat după 340 de ani din inițiativa și purtarea de grijă a Prea Sfințitului Emilian, Episcopul Alba Iuliei, Editura

Episcopiei Ortodoxe a Alba Iuliei, 1988.

NT Cat $=$ Noul Testament . Traducere de Alois Bulai și Anton Budău, Sapientia, Iaşi, 2002.

P 1652 = Îndreptarea legii. 1652, Ediție critică, Editura Academiei, București, 1962.

$\mathrm{PDL}=$ Perseus Digital Library [online].

PH = Psaltirea Hurmuzaki. I, Studiu filologic, studiu lingvistic și ediție de Ion Gheție și Mirela Teodorescu; II, Indice de cuvinte

de Rovena Șenchi, Editura Academiei Române, București, 2005.

PS = Psaltirea scheiană comparată cu celelalte Psaltiri din sec. XVIși XVII traduse din slavonește, edițiune critică de I.-A. Candrea,

București, 1916.

$\mathrm{PV}=$ Psaltirea voronețeană, BAR, ms. rom. 693; colaționare, Roxana Vieru [online].

TLG = Thesaurus Lingue Grece [online].

vUL = Biblia Sacra Juxta Vulgatam Versionem (Vulgate Latin Bible). Edited by R. Weber, B. Fischer, J. Gribomont, H.F.D.

Sparks, and W. Thiele [at Beuron and Tuebingen].

\section{B. Lucrări de referință}

BAILly = Bailly, A., Dictionnaire Greque-Français, Hachette, Paris, [s.a.]. 
Chirilă, A. (2013). Limba scrierilor lui Antim Ivireanul. I. Fonetica. Morfologia, Editura Universității „Alexandru Ioan Cuza”, Iași.

Costinescu, M. (1980). Biblia lui Luther, unul din izvoarele Apostolului coresian, în LR, 29 (2), p. 127-[139] (în revistă: „127137”; în fapt, eroare de paginație).

Darmesteter, A. (2015). Viața cuvintelor studiată în semnificațiile lor, traducere din limba franceză de Alexandru Gafton, Editura Universității „Alexandru Ioan Cuza”, Iași.

Dormeyer, D. (2004). The Hellenistic Letter-Formula and the Pauline Letter-Scheme, în Porter, S.E. (ed.), The Pauline Canon. Pauline Studies. I., Brill, Leiden/Boston, p. 59-94, Crossref.

Fecioru, D. (2016). Note la Clement Alexandrinul, Pedagogul, în Părinți și scriitori bisericești. Serie nouă, 16. Clement Alexandrinul, Sfântul Vasile cel Mare, Sfântul Ioan Gură de Aur, Sfântul Grigorie Teologul, Fericitul Ieronim, Fericitul Augustin, Scrieri cu tematică pedagogică, Basilica, București, p. 69-310.

Frățilă, V. (2005). Graiul de pe Târnave, Editura ASTRA, Despărțământul „Timotei Cipariu”, Blaj.

Frâncu, C. (2009). Gramatica limbii române vechi (1521-1780), Casa Editorială „Demiurg”, Iași.

FRIBERG = Friberg, B., Friberg, T. \& Miller, N. F. (2000). Analytical Lexicon of the Greek New Testament, Baker Books, [s.l.].

Lang, F. (1995). Theologisches Wörterbuch zum Neuen Testament. Siebenter Band, 2.Teil, S [TDNT, VII]. Editors: Gerhard Kittel, Gerhard Friedrich. Translated by Goeffrey W. Bromiley, Stuttgart.

LIDDELl-scotT = Liddell, H.G. \& Scott, R., A Greek-English Lexicon, Compiled by.... A New Edition Revised and Augmented throughout by Sir Henry Stuart Jones, Oxford, [s.a.].

LOUW-NIDA = Louw, J.E. \& Nida, E.A. (eds.), Greek-English Lexicon of The New Testament Based on Semantic Domains, Vol. I-II, Second Edition, United Bible Societies, New York, 1988, 1989.

MIKLOSICH = Miklosich, Fr., Lexicon palaoslovenico-greco-latinum, Gulelmus Braumueller, Vindobonæ, 1862-1865.

MIKLOSICH ${ }_{2}=$ Miklosich, Fr., Lexicon lingue slovenice veteris dialecti, Vindobonæ, 1850.

MLD = Monumenta lingua dacoromanorum. Biblia 1688. Pars XXIV. Novum Testamentum II: Actus Apostolorum, Pauli Epistole, Catholice Epistole, Iude, Apocalypsis Ioannis, Editura Universității „Alexandru Ioan Cuza”, Iași.

Moldovanu, D. (2009). Finalitatea textelor slavo-române intercalate din Evul Mediu românesc, în „Text și discurs religios”, 1, p. $103-123$.

Plantin, C. (2004). On the Inseparability of Emotion and Reason in Argumentation, în Weigand, E. (ed.), Emotion in Dialogic Interaction. Advances in the complex, John Benjamins Publishing Company, Amsterdam, p. 269-280, Crossref.

Rosetti, Al. (1978). Istoria limbii române. De la origini pînă în secolul al XVII-lea, Editura Științifică și Enciclopedică, București. Trudgill, P. (1981). Sociolinguistics: An Introduction, Penguin Books, [s.1.]. 